\title{
Indian Banking Sector - Challenges and Opportunities
}

\author{
Dr. K. Ratna Manikyam \\ Lecturer, Department of Commerce, Sri A.S.N.M. Government College \\ PALAKOL - 534260, W.G. Dist., A.P., India
}

\begin{abstract}
The economic reforms initiated by the Government of India about two decades ago have changed the landscape of several sectors of the Indian economy. The Indian banking sector is no exception. This sector is going through major changes as a consequence of economic reforms. The role of banking industry is very important as one of the leading and mostly essential service sector. India is the largest economy in the world having more than 120 crore population. Today in India the service sector is contributing half of the Indian GDP and the banking is most popular service sector in India. The significant role of banking industry is essential to speed up the social economic development. Banks plays an important role in the economic development of developing countries. Economic development involves investment in various sectors of the economy.

The economic reforms have also generated new and powerful customers (huge Indian middle class) and new mix of players (public sector units, private banks, and foreign banks). The emerging competition has generated new expectations from the existing and the new customers. There is an urgent need to introduce new products. Existing products need to be delivered in an innovative and cost-effective way by taking full advantage of emerging technologies. The biggest opportunity for the Indian banking system today is the Indian consumer. Demographic shifts in terms of income levels and cultural shifts in terms of lifestyle aspirations are changing the profile of the Indian consumer. The Indian consumer now seeks to fulfil his lifestyle aspirations at a younger age with an optimal combination of equity and debt to finance consumption and asset creation. This is leading to a growing demand for competitive, sophisticated retail banking services. This paper explains the changing banking scenario, the impact of economic reforms and analyses the challenges and opportunities of national and commercial banks.
\end{abstract}

Keywords: E-Banking, Customer Retention, Economic Reforms, Information Technology, lifestyle, GDP, CRM

\section{Introduction}

India is one of the top 10 economies in the world, where the banking sector has tremendous potential to grow. The last decade saw customers embracing ATM, internet and mobile banking. India's banking sector is currently valued at Rs. 81 trillion (US\$ 1.31 trillion). It has the potential to become the fifth largest banking industry in the world by 2020 and the third largest by 2025 , according to an industry report. The face of Indian banking has changed over the years. Banks are now reaching out to the masses with technology to facilitate greater ease of communication, and transactions are carried out through the Internet and mobile devices.

A bank is a financial institution that provides banking and other financial services to their customers. A bank is generally understood as an institution which provides fundamental banking services such as accepting deposits and providing loans. There are also nonbanking institutions that provide certain banking services without meeting the legal definition of a bank. Banks are a subset of the financial services industry. A banking system also referred as a system provided by the bank which offers cash management services for customers, reporting the transactions of their accounts and portfolios, throughout the day.

The banking system in India should not only be hassle free but it should be able to meet the new challenges posed by the technology and any other external and internal factors. For the past three decades, India's banking system has several outstanding achievements to its credit. The Banks are the main participants of the financial system in India. The Banking sector offers several facilities and opportunities to their customers. All the banks safeguards the money and valuables and provide loans, credit, and payment services, such as checking accounts, money orders, and cashier's cheques. The banks also offer investment and insurance products. As a variety of models for cooperation and integration among finance industries have emerged, some of the traditional distinctions between banks, insurance companies, and securities firms have diminished. In spite of these changes, banks continue to maintain and perform their primary role-accepting deposits and lending funds from these deposits.

Before the establishment of banks, the financial activities were handled by money lenders and individuals. At that time the interest rates were very high. Again there were no security of public savings and no uniformity regarding loans. So as to overcome such problems the organized banking sector was established, which was fully regulated by the government. The organized banking sector works within the financial system to provide loans, accept deposits and provide other services to their customers. The following functions of the bank explain the need of the bank and its importance: 
- To provide the security to the savings of customers.

- To control the supply of money and credit

- To encourage public confidence in the working of the financial system, increase savings speedily and efficiently.

- To avoid focus of financial powers in the hands of a few individuals and institutions.

- To set equal norms and conditions (i.e. rate of interest, period of lending etc.) to all types of Customers.

\section{OBJECTIVE}

The objective of this paper is to explain the changing banking scenario, to analyze the impact of liberalization, privatization \& globalization and to study the challenges and opportunities of national and commercial banks in changing banking scenario. In addition to this, an attempt is made to understand the significance of banks in India.

\section{Methodology}

This paper is the outcome of a secondary data on Indian Banking Sector with special reference to Indian context. To complete this, annual reports, various books, journals and periodicals have been consulted, several reports on this particular area have been considered, and internet searching has also been done.

\section{Evolution of the Indian Banking Industry}

The first bank in India, called The General Bank of India was established in the year 1786. The East India Company established The Bank of Bengal/Calcutta (1809), Bank of Bombay (1840) and Bank of Madras (1843). The next bank was Bank of Hindustan which was established in 1870. These three individual units (Bank of Calcutta, Bank of Bombay, and Bank of Madras) were called as Presidency Banks. Allahabad Bank which was established in 1865, was for the first time completely run by Indians. Punjab National Bank Ltd. was set up in 1894 with headquarters at Lahore. Between 1906 and 1913, Bank of India, Central Bank of India, Bank of Baroda, Canara Bank, Indian Bank, and Bank of Mysore were set up. In 1921, all presidency banks were amalgamated to 22 forms the Imperial Bank of India which was run by European Shareholders. After that the Reserve Bank of India was established in April 1935.

At the time of first phase the growth of banking sector was very slow. Between 1913 and 1948 there were approximately 1100 small banks in India. To streamline the functioning and activities of commercial banks, the Government of India came up with the Banking Companies Act, 1949 which was later changed to Banking Regulation Act 1949 as per amending Act of 1965 (Act No.23 of 1965). Reserve Bank of India was vested with extensive powers for the supervision of banking in India as a Central Banking Authority.

After independence, Government has taken most important steps in regard of Indian Banking Sector reforms. In 1955, the Imperial Bank of India was nationalized and was given the name "State Bank of India", to act as the principal agent of RBI and to handle banking transactions all over the country. It was established under State Bank of India Act, 1955. Seven banks forming subsidiary of State Bank of India was nationalized in 1960. On 19th July, 1969, major process of nationalization was carried out. At the same time 14 major Indian commercial banks of the country were nationalized. In 1980, another six banks were nationalized, and thus raising the number of nationalized banks to 20 . Seven more banks were nationalized with deposits over 200 crores. Till the year 1980 approximately $80 \%$ of the banking segment in India was under government's ownership. On the suggestions of Narsimhan Committee, the Banking Regulation Act was amended in 1993 and thus the gates for the new private sector banks were opened.

The following are the major steps taken by the Government of India to Regulate Banking institutions in the country:-

1949: Enactment of Banking Regulation Act.

1955: Nationalisation of State Bank of India.

1959: Nationalization of SBI subsidiaries.

1961: Insurance cover extended to deposits.

1969: Nationalisation of 14 major Banks.

1971: Creation of credit guarantee corporation.

1975: Creation of regional rural banks.

1980: Nationalisation of seven banks with deposits over 200 Crores.

\section{Phases of Evolution of Indian Banking Industry}

In the evolution of this strategic industry spanning over two centuries, immense developments have been made in terms of the regulations governing it, the ownership structure, products and services offered and the technology deployed. The entire evolution can be classified into four distinct phases.

- Phase I- Pre-Nationalisation Phase (prior to 1955) 
- Phase II- Era of Nationalisation and Consolidation (1955-1990)

- Phase III- Introduction of Indian Financial \& Banking Sector Reforms and Partial Liberalisation (19902004)

- Phase IV- Period of Increased Liberalisation (2004 onwards)

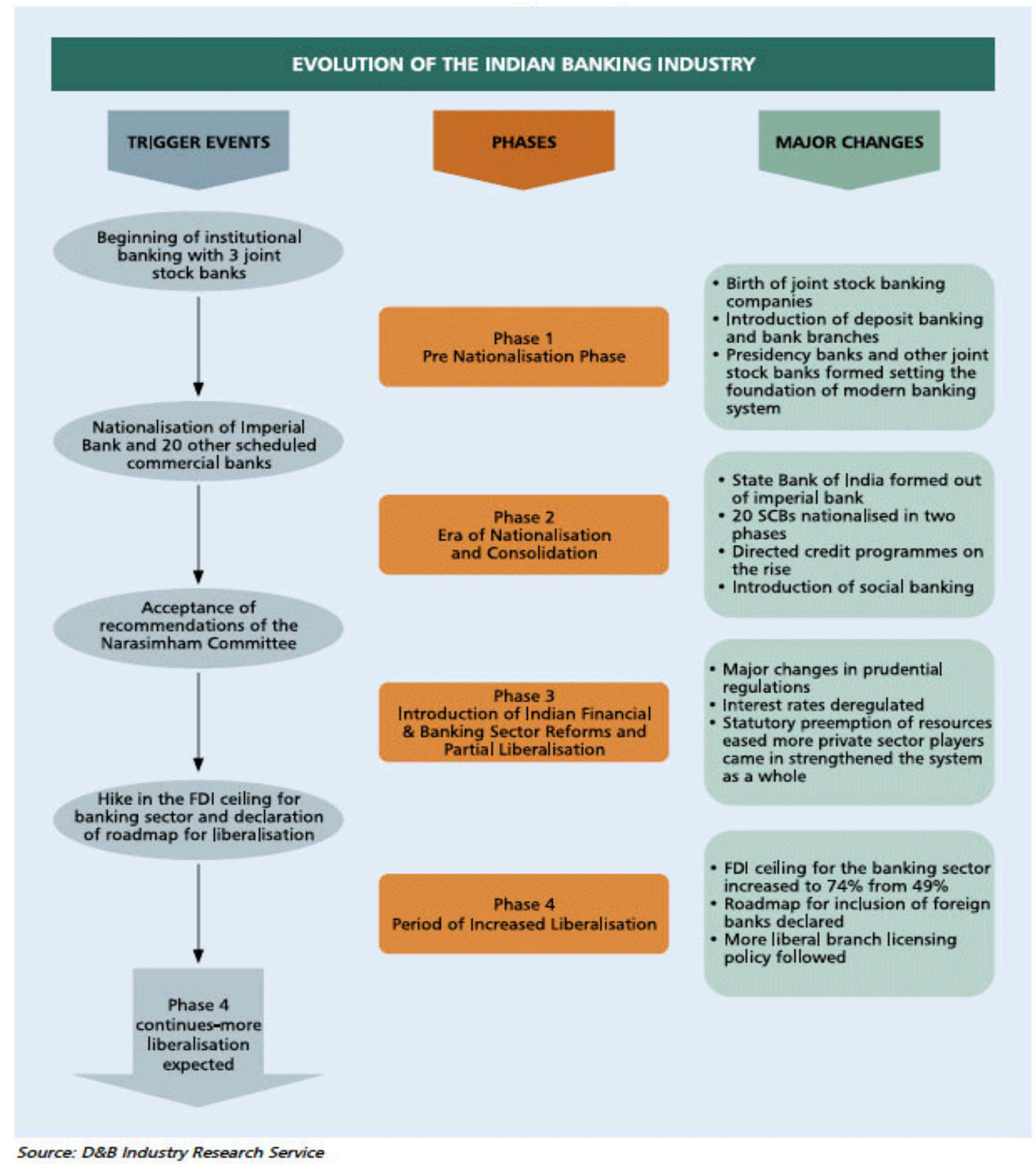

\section{ORGANISATIONAL STRUCTURE}

Indian banking industry has a diverse structure. The present structure of the Indian banking industry has been analysed on the basis of its organised status, business as well as product segmentation. The entire organised banking system comprises of scheduled and non-scheduled banks. Largely, this segment comprises of the scheduled banks, with the unscheduled ones forming a very small component. Banking needs of the financially excluded population is catered to by other unorganised entities distinct from banks, such as, moneylenders, pawnbrokers and indigenous bankers. 


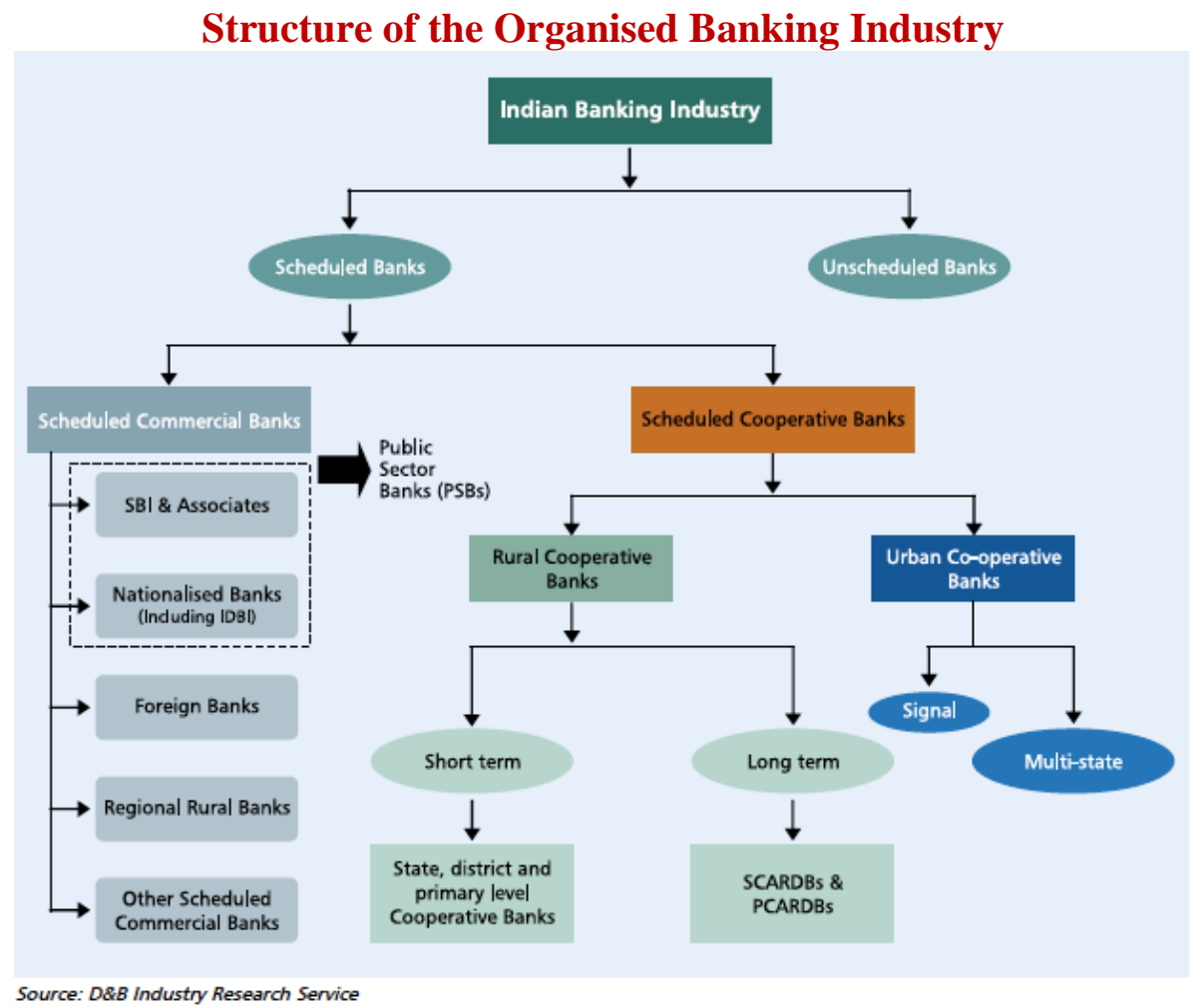

\section{Scheduled Banks}

A scheduled bank is a bank that is listed under the second schedule of the RBI Act, 1934. In order to be included under this schedule of the RBI Act, banks have to fulfil certain conditions such as having a paid up capital and reserves of at least 0.5 million and satisfying the Reserve Bank that its affairs are not being conducted in a manner prejudicial to the interests of its depositors. Scheduled banks are further classified into commercial and cooperative banks. The basic difference between scheduled commercial banks and scheduled cooperative banks is in their holding pattern. Scheduled cooperative banks are cooperative credit institutions that are registered under the Cooperative Societies Act. These banks work according to the cooperative principles of mutual assistance.

\section{Scheduled Commercial Banks (SCBs)}

Scheduled commercial banks (SCBs) account for a major proportion of the business of the scheduled banks. As at end-March, 2009, 80 SCBs were operational in India. SCBs in India are categorized into the five groups based on their ownership and/or their nature of operations. State Bank of India and its six associates (excluding State Bank of Saurashtra, which has been merged with the SBI with effect from August 13, 2008) are recognised as a separate category of SCBs, because of the distinct statutes (SBI Act, 1955 and SBI Subsidiary Banks Act, 1959) that govern them. Nationalised banks (10) and SBI and associates (7), together form the public sector banks group and control around 70\% of the total credit and deposits businesses in India. IDBI ltd. has been included in the nationalised banks group since December 2004. Private sector banks include the old private sector banks and the new generation private sector banks- which were incorporated according to the revised guidelines issued by the RBI regarding the entry of private sector banks in 1993. As at end-March 2009, there were 15 old and 7 new generation private sector banks operating in India.

Foreign banks are present in the country either through complete branch/subsidiary route presence or through their representative offices. At end-June 2009, 32 foreign banks were operating in India with 293 branches. Besides, 43 foreign banks were also operating in India through representative offices.

Regional Rural Banks (RRBs) were set up in September 1975 in order to develop the rural economy by providing banking services in such areas by combining the cooperative specialty of local orientation and the sound resource base which is the characteristic of commercial banks. RRBs have a unique structure, in the sense that their equity holding is jointly held by the central government, the concerned state government and the sponsor bank (in the ratio 50:15:35), which is responsible for assisting the RRB by providing financial, managerial and training aid and also subscribing to its share capital.

Between 1975 and 1987, 196 RRBs were established. RRBs have grown in geographical coverage, reaching out to increasing number of rural clientele. At the end of June 2008, they covered 585 out of the 622 districts of the country. Despite growing in geographical coverage, the number of RRBs operational in the 
country has been declining over the past five years due to rapid consolidation among them. As a result of state wise amalgamation of RRBs sponsored by the same sponsor bank, the number of RRBs fell to 86 by end March 2009.

\section{Scheduled Cooperative Banks}

Scheduled cooperative banks in India can be broadly classified into urban credit cooperative institutions and rural cooperative credit institutions. Rural cooperative banks undertake long term as well as short term lending. Credit cooperatives in most states have a three tier structure (primary, district and state level).

\section{Non-Scheduled Banks}

Non-scheduled banks also function in the Indian banking space, in the form of Local Area Banks (LAB). As at end-March 2009 there were only 4 LABs operating in India. Local area banks are banks that are set up under the scheme announced by the government of India in 1996, for the establishment of new private banks of a local nature; with jurisdiction over a maximum of three contiguous districts. LABs aid in the mobilisation of funds of rural and semi urban districts. Six LABs were originally licensed, but the license of one of them was cancelled due to irregularities in operations, and the other was amalgamated with Bank of Baroda in 2004 due to its weak financial position.

\section{Business Segmentation}

The entire range of banking operations are segmented into four broad heads- retail banking businesses, wholesale banking businesses, treasury operations and other banking activities. Banks have dedicated business units and branches for retail banking, wholesale banking (divided again into large corporate, mid corporate) etc.

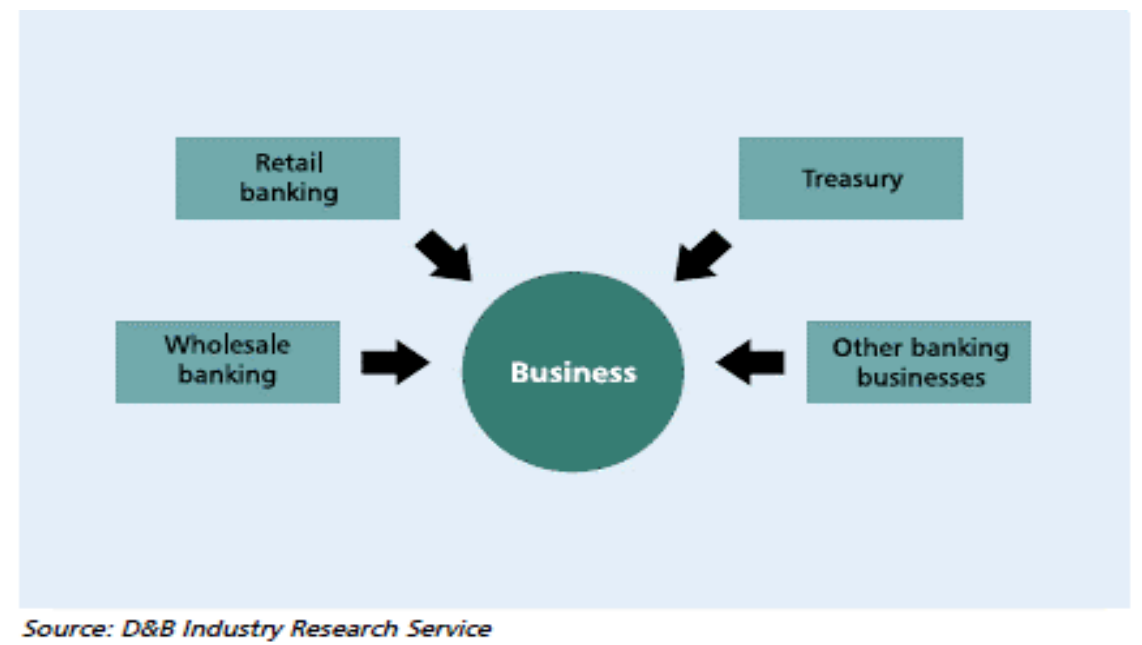

\section{Retail Banking}

It includes exposures to individuals or small businesses. Retail banking activities are identified based on four criteria of orientation, granularity, product criterion and low value of individual exposures. In essence, these qualifiers imply that retail exposures should be to individuals or small businesses (whose annual turnover is limited to Rs. 0.50 billion) and could take any form of credit like cash credit, overdrafts etc. Retail banking exposures to one entity is limited to the extent of $0.2 \%$ of the total retail portfolio of the bank or the absolute limit of Rs. 50 million. Retail banking products on the liability side includes all types of deposit accounts and mortgages and loans (personal, housing, educational etc) on the assets side of banks. It also includes other ancillary products and services like credit cards, demat accounts etc.

The retail portfolio of banks accounted for around $21.3 \%$ of the total loans and advances of SCBs as at end-March 2009. The major component of the retail portfolio of banks is housing loans, followed by auto loans. Retail banking segment is a well-diversified business segment. Most banks have a significant portion of their business contributed by retail banking activities. The largest players in retail banking in India are ICICI Bank, SBI, PNB, BOI, HDFC and Canara Bank.

Among the large banks, ICICI bank is a major player in the retail banking space which has had definitive strategies in place to boost its retail portfolio. It has a strong focus on movement towards cheaper channels of distribution, which is vital for the transaction intensive retail business. SBI's retail business is also fast growing and a strategic business unit for the bank. Among the smaller banks, many have a visible presence especially in the auto loans business. Among these banks the reliance on their respective retail portfolio is high, as many of these banks have advance portfolios that are concentrated in certain usages, such as auto or 
consumer durables. Foreign banks have had a somewhat restricted retail portfolio till recently. However, they are fast expanding in this business segment. The retail banking industry is likely to see a high competition scenario in the near future.

\section{Wholesale Banking}

Wholesale banking includes high ticket exposures primarily to corporates. Internal processes of most banks classify wholesale banking into mid corporates and large corporates according to the size of exposure to the clients. A large portion of wholesale banking clients also account for off balance sheet businesses. Hedging solutions form a significant portion of exposures coming from corporates. Hence, wholesale banking clients are strategic for the banks with the view to gain other business from them. Various forms of financing, like project finance, leasing finance, finance for working capital, term finance etc. form part of wholesale banking transactions. Syndication services and merchant banking services are also provided to wholesale clients in addition to the variety of products and services offered.

Wholesale banking is also a well-diversified banking vertical. Most banks have a presence in wholesale banking. But this vertical is largely dominated by large Indian banks. While a large portion of the business of foreign banks comes from wholesale banking, their market share is still smaller than that of the larger Indian banks. A number of large private players among Indian banks are also very active in this segment. Among the players with the largest footprint in the wholesale banking space are SBI, ICICI Bank, IDBI Bank, Canara Bank, Bank of India, Punjab National Bank and Central Bank of India. Bank of Baroda has also been exhibiting quite robust results from its wholesale banking operations.

\section{Treasury Operations}

Treasury operations include investments in debt market (sovereign and corporate), equity market, mutual funds, derivatives, and trading and forex operations. These functions can be proprietary activities, or can be undertaken on customer's account. Treasury operations are important for managing the funding of the bank. Apart from core banking activities, which comprises primarily of lending, deposit taking functions and services; treasury income is a significant component of the earnings of banks. Treasury deals with the entire investment portfolio of banks (categories of HTM, AFS and HFT) and provides a range of products and services that deal primarily with foreign exchange, derivatives and securities. Treasury involves the front office (dealing room), mid office (risk management including independent reporting to the asset liability committee) and back office (settlement of deals executed, statutory funds management etc).

\section{Other Banking Businesses}

This is considered as a residual category which includes all those businesses of banks that do not fall under any of the aforesaid categories. This category includes para banking activities like hire purchase activities, leasing business, merchant banking, factoring activities etc.

\section{PRODUCTS OF BANKING INDUSTRY}

The products of the banking industry broadly include deposit products, credit products and customized banking services. Most banks offer the same kind of products with minor variations. The basic differentiation is attained through quality of service and the delivery channels that are adopted. Apart from the generic products like deposits (demand deposits - current, savings and term deposits), loans and advances (short term and long term loans) and services, there have been innovations in terms and products such as the flexible term deposit, convertible savings deposit (wherein idle cash in savings account can be transferred to a fixed deposit), etc. Innovations have been increasingly directed towards the delivery channels used, with the focus shifting towards ATM transactions, phone and internet banking. Product differentiating services have been attached to most products, such as debit/ATM cards, credit cards, nomination and demat services.

\section{Products and Services}

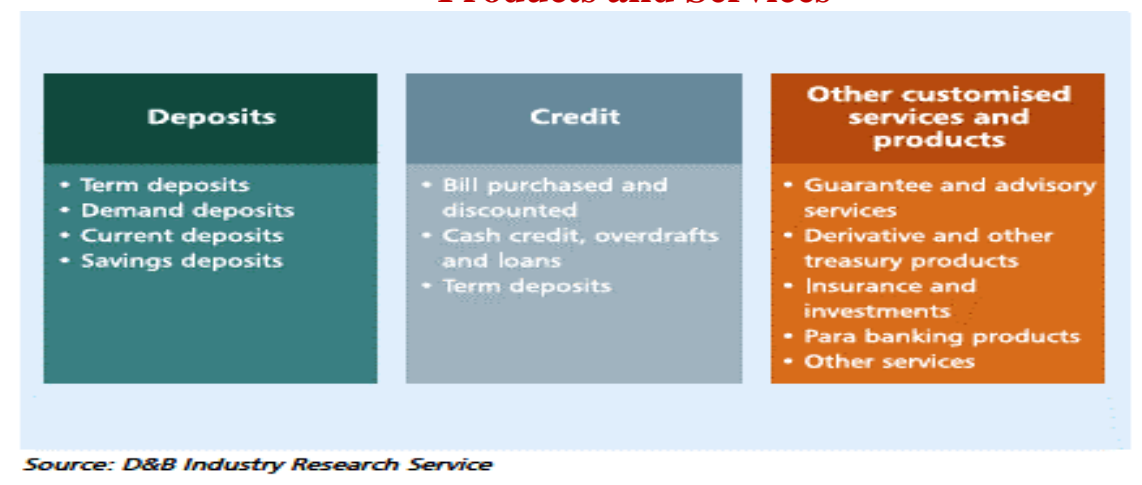


Other banking products include fee-based services that provide non-interest income to the banks. Corporate fee-based services offered by banks include treasury products; cash management services; letter of credit and bank guarantee; bill discounting; factoring and forfeiting services; foreign exchange services; merchant banking; leasing; credit rating; underwriting and custodial services. Retail fee-based services include remittances and payment facilities, wealth management, trading facilities and other value added services.

\section{CHALLENGES AND OPPORTUNITIES}

The Indian banking sector continues to face some structural challenges. We have a relatively large number of banks, some of which are sub-optimal in size and scale of operations. On the regulatory front, alignment with global developments in banking supervision is a focus area for both regulators and banks. The new international capital norms require a high level of sophistication in risk management, information systems, and technology which would pose a challenge for many participants in the Indian banking sector. The deep and often painful process of restructuring in the Indian economy and Indian industry has resulted in asset quality issues for the banking sector; while significant progress is being made in this area, a great deal of work towards resolution of these legacy issues still needs to be done. The Indian banking sector is thus at an exciting point in its evolution. The opportunities are immense - to enter new businesses and new markets, to develop new ways of working, to improve efficiency, and to deliver higher levels of customer service. The process of change and restructuring that must be undergone to capitalize on these opportunities poses a challenge for many banks.

The Indian banking sector is faced with multiple and concurrent challenges such as increased competition, rising customer expectations, and diminishing customer loyalty. The banking industry is also changing at a phenomenal speed. While at the one end, we have millions of savers and investors who still do not use a bank, another segment continues to bank with a physical branch and at the other end of the spectrum, the customers are becoming familiar with ATMs, e-banking, and cashless economy. This shows the immense potential for market expansion. The exponential growth for the industry comes from being able to handle as wide a range of this spectrum as possible. In this complex and fast changing environment, the only sustainable competitive advantage is to give the customer an optimum blend of technology and traditional service.

As banks develop their strategies for giving customers access to their accounts through various advanced services like e banking, mobile banking and net banking, they should also regard this emerging platform as a potential catalyst for generating operational efficiencies and as a vehicle for new revenue sources. Banking industry's opportunities includes

- A growing economy

- Banking deregulation

- Increased client borrowing

- An increase in the number of banks

- An increase in the money supply

- Low government-set credit rates and

Larger customer checking account balances. Developing countries like India, has a huge number of people who don't have access to banking services due to scattered and fragmented locations. But if we talk about those people who are availing banking services, their expectations are raising as the level of services are increasing due to the emergence of Information Technology and immense competition between the services and products provided by different banks. Since, foreign banks are playing in Indian market, the number of services of offered has increased and banks have laid emphasis on meeting the customer expectations.

India's banking sector has made rapid strides in reforming and aligning itself to the new competitive business environment. The major challenges faced by banks today are as to how to cope withcompetit ive forces and strengthen their balance sheet. Today, banks are groaning with burden of NPA's. It is rightly felt that these contaminated debts, if not recovered, will eat into the very vitals of the banks.

\section{Indian Consumer}

The biggest opportunity for the Indian banking system today is the Indian consumer. Demographic shifts in terms of income levels and cultural shifts in terms of lifestyle aspirations are changing the profile of the Indian consumer. This is and will be a key driver of economic growth going forward. The Indian consumer now seeks to fulfil his lifestyle aspirations at a younger age with an optimal combination of equity and debt to finance consumption and asset creation. This is leading to a growing demand for competitive, sophisticated retail banking services. The consumer represents a market for a wide range of products and services - he needs a mortgage to finance his house; an auto loan for his car; a credit card for on-going purchases; a bank account; a long-term investment plan to finance his child's higher education; a pension plan for his retirement; a life insurance policy - the possibilities are endless. And, this consumer does not live just in India's top ten cities. He is present across cities, towns, and villages as improving communications increases awareness even in small 
towns and rural areas. Consumer goods companies are already tapping this potential - it is for the banks to make the most of the opportunity to deliver solutions to this market.

\section{Revolution of Information Technology}

Technology is the key to servicing all customer segments - offering convenience to the retail customer and operating efficiencies to corporate and government clients. The increasing sophistication, flexibility, and complexity of product and servicing offerings makes the effective use of technology critical for managing the risks associated with the business. Developing or acquiring the right technology, deploying it optimally, and then leveraging it to the maximum extent is essential to achieve and maintain high service and efficiency standards while remaining cost-effective and delivering sustainable returns to shareholders. Early adopters of technology acquire significant competitive advantage. Managing technology is, therefore, a key challenge for the Indian banking sector. Wide disparities exist between various banks as far as technology capabilities are concerned; the sector as a whole needs to make significant progress on this front.

Banks may have to go for mobile banking services for a cluster of villages. Alternatively, technological institutions have to come out with low-cost, self-service solutions/ ATMs. The government and the RBI should actively support such research efforts. Here, it is worthwhile to mention that the adaptability of the Indian rural population to high-tech devices is one of the fastest in the world. A wider dissemination of information on technologies and products to the Indian banking industry by the research institutions could benefit the banking institutions. This cross-pollination of ideas would mutually enrich the banking and the technology development processes. The Indian banks are subject to tremendous pressures to perform as otherwise their very survival would be at stake. The application of IT and e-banking is becoming the order of the day with the banking system heading towards virtual banking.

\section{Industrial Development}

The developments in Indian industry and government and the integration of India with the global markets also offer innumerable opportunities to the banking sector. Companies and governments are increasingly seeking high-quality banking services to improve their own operating efficiency. Companies seek to offer better customer service and maximize shareholder returns and governments seek to improve the quality of public services. The internationalization of India offers banks the opportunity to service cross-border needs of Indian companies and India-linked needs of multinationals.

\section{Knowledged Society}

Building knowledge-driven, learning organizations is important in the current scenario of rapidly evolving operating environments. Knowledge and assimilation of new ideas and trends are essential to keep the organization ahead on the curve. This is true for banking as it is for all other sectors. Banks must continuously seek to be aware of cutting edge practices in banking internationally and institutionalize this learning across the organization. This will prepare them for the future as Indian markets become more sophisticated and integrated into the global financial markets. Another critical area for the Indian banking sector is people. The ability to attract and retain talent is a key success factor for a people-oriented business like banking. Banks have to build organizations that are process driven yet innovative, stable yet flexible, and responsive to change.

\section{Intense Competition}

The RBI and Government of India kept banking industry open for the participants of private sector banks and foreign banks. The foreign banks were also permitted to set up shop on India either as branches or as subsidiaries. Due to this lowered entry barriers many new players have entered the marketsuchasprivate banks, foreign banks, nonbanking finance companies, etc. The foreign banks and new private sector banks have spearhead the hi-tech revolution. For survival and growth in highly competitive environment banks have to follow the prompt and efficient customer service, which calls for appropriate customer centric policies and customer friendly procedures.

\section{Employees' Retention}

The banking industry has transformed rapidly in the last ten years, shifting from transactional and customer service-oriented to an increasingly aggressive environment, where competition for revenue is on top priority. Long-time banking employees are becoming disenchanted with the industry and are often resistant to perform up to new expectations. The diminishing employee morale results in decreased revenue. Due to the intrinsically close ties between staff and clients, losing those employees completely can mean the loss of valuable customer relationships. There tail banking industry is concerned about employee retention from all levels: from tellers to executives to customer service representatives because competition is always moving in to hire them away. 


\section{Financial inclusion}

Financial inclusion has become a necessity in today's business environment. Whatever is produced by business houses that have to be under the check from various perspectives like environmental concerns, corporate governance, social and ethical issues. Apart from it to bridge the gap between rich and poor, the poor people of the country should be given proper attention to improve their economic condition. In India, RBI has initiated several measures to achieve greater financial inclusion, such as facilitating no-frills accounts and GCCs for small deposits and credit.

\section{Rural Market}

Banking in India is generally fairly mature in terms of supply, product range and reach, even though reach in rural India still remains a challenge for the private sector and foreign banks. In terms of quality of assets and capital adequacy, Indian banks are considered to have clean, strong and transparent balance sheets relative to other banks in comparable economies in its region. Consequently, we have seen some examples of inorganic growth strategy adopted by some nationalized and private sector banks to face upcoming challenges in banking industry of India. For example recently, ICICI Bank Ltd. merged the Bank of Rajasthan Ltd. in order to increase its reach in rural market and market share significantly. State Bank of India (SBI), the largest public sector bank in India has also adopted the same strategy to retain its position. It is in the process of acquiring its associates. Recently, SBI has merged State Bank of Indore in 2010.

\section{High Transaction Costs}

A major concern before the banking industry is the high transaction cost of carrying non- performing assets in their books. The growth led to strains in the operational efficiency of banks and the accumulation of non-performing assets (NPA's) in their loan portfolios.

\section{Social and Ethical Aspects}

There are some banks, which proactively undertake the responsibility to bear the social and ethical aspects of banking. This is a challenge for commercial banks to consider these aspects in their working. Apart from profit maximization, commercial banks are supposed to support those organizations, which have some social concerns.

\section{Timely Technological up gradation}

Already electronic transfers, clearings, settlements have reduced translation times. To face competition it is necessary for banks to absorb the technology and upgrade their services.

\section{Global banking}

The impact of globalization becomes challenges for the domestic enterprises as they are bound to compete with global players. If we look at the Indian Banking Industry, then we find that there are 36 foreign banks operating in India, which becomes a major challenge for Nationalized and private sector banks.

\section{Conclusion}

The pre and post liberalization era has witnessed various environmental changes which directly affects the aforesaid phenomena. It is evident that post liberalization era has spread new colours of growth in India, but simultaneously it has also posed some challenges. This article discusses the various challenges and opportunities like High transaction costs, IT revolution, timely technological up-gradation, intense competition, privacy \& safety, global banking, financial inclusion. Banks are striving to combat the competition. The competition from global banks and technological innovation has compelled the banks to rethink their policies and strategies. Different products provided by foreign banks to Indian customers have forced the Indian banks to diversity and upgrade themselves so as to compete and survive in the market.

The biggest challenge for banking industry is to serve the mass and huge market of India. Companies have become customer centric than product centric. The better we understand our customers, the more successful we will be in meeting their needs. In order to mitigate above mentioned challenges Indian banks must cut their cost of their services. Another aspect to encounter the challenges is product differentiation. Apart from traditional banking services, Indian banks must adopt some product innovation so that they can compete in gamut of competition. Technology up gradation is an inevitable aspect to face challenges. The level of consumer awareness is significantly higher as compared to previous years. Now-a-days they need internet banking, mobile banking and ATM services. 


\section{References}

[1]. Alpesh Shah et.al., Indian Banking 2020: Making the Decade‘s Promise Come True, www.bcg.com, www.ficci-banking.com, www.iba.org.in

[2]. Bartel, A. P. (2004). "Human Resource Management and Organizational Performance: Evidence from Retail Banking". Industrial and Labour Relations Review, 57(2): 181-203.

[3]. Chellaswamy P. (2010), "Modern Banking Management", Himalaya Publishing House.

[4]. Clark, M. (1997) "Modelling the Impact of Customer-Employee Relationships on Customer Retention Rates in a Major UK Retail Bank". Management Decision, 35(4): 293-301.

[5]. Dev, S. M. "Financial Inclusion: Issues and Challenges". Economic \& Political Weekly

[6]. Export Import Bank of India, www.eximbankindia.com

[7]. Goyal, K. A. and Joshi, V. (2012) "A Study of Social and Ethical Issues in Major Announcements in the Union Budget 2012-13 for the Banking Sector.

[8]. Goyal, K. A. and Joshi, V. "A Study of Social and Ethical Issues in Banking Industry", International Journal of Economics \& Research (IJER), 2011 2(5), pp. 49-57.

[9]. Goyal, K. A. and Joshi, V. "Mergers in Banking Industry of India: Some Emerging Issues". Asian Journal of Business and Management Sciences, 1(2): 157-165, 2011a.

[10]. Gupta V, (2004) "Risks of E - banking in India" in E-Banking, the ICFAI University Press.

[11]. Hansemark, O. C. and Albinsson, M. (2004) "Customer Satisfaction and Retention: The Experiences of Individual Employees". Managing Service Quality, 14(1): $40-57$

[12]. IBEF (India Brand Equity foundation), www.ibef.org

[13]. Industrial Investment Bank of India Ltd., www.iibiltd.com

[14]. Jugale V.B, "Banking trends in India"

[15]. K.A. Goyal \& Vijay Joshi, (2012) International Journal of Business Research and Management (IJBRM), Volume (3): Issue. 1

[16]. Kulkarni R V (2000), "Changing Face of Banking from Brick and Mortar Banking to E -Banking"

[17]. Levesque, T. and McDougall, G.H.G. "Determinants of Customer Satisfaction in Retail

[18]. McKinsey report, (2012) - Human Capital is the Key to Unlocking a Golden Decade in Indian Banking Indian Banking Industry.

[19]. National Bank for Agriculture and Rural Development (NABARD), www.nabard.org

[20]. National Housing Bank, www.nhb.org.in

[21]. Rajkumar S Adukia, An Overview of Banking Sector in India, www.caaa.in

[22]. Reserve Bank of India, www.rbi.org.in

[23]. Sekaran, U. (1989), "Paths to the job satisfaction of bank employees". Journal of Organizational Behaviour, 10(4): 347-359.

[24]. Shrieves, R. E. "The Relationship between Risk and Capital in Commercial Banks" Journal of Banking \& Finance

[25]. Small Industries Development Bank of India, www.sidbi.com

[26]. Survey Evidence", The ICFAI Journal of Bank Management.

[27]. Terrence Levesque and Gordon H.G. McDougall (1996), Determinants of Customer Satisfaction in Retail Banking” International Journal of Bank Marketing, 14(7): 12 - 20.

[28]. The Indian Banking Sector: Recent Developments, Growth and Prospects, (2013)

[29]. Uppal R.K., "Customer Perception of E - Banking Services of Indian Banks: Some Survey Evidence

[30]. Zhao, T., Casu, B. and Ferrari, A. (2008), "Deregulation and Productivity Growth: A Study of the Indian Commercial Banking Industry". International Journal of Business Performance Management, 10(4): 318-343.

[31]. en.wikipedia.org/wiki/Commercial bank

[32]. en.wikipedia.org/wiki/Cooperative banking

[33]. www.preservearticles.com/201012291875/indigenous-bankers.html

[34]. www.banknetindia.com/banking/boverview.htm

[35]. www.banknetindia.com/banking/boverview.htm

[36]. $\quad$ www.ibef.org 